\title{
Pemanfaatan Lingkungan Sekolah Sebagai Sumber Belajar IPS oleh Guru-Guru SMP Negeri Kecamatan Sragen
}

\section{Oktania Nelly Kusani, Tukidi, Aisyah Nur Sayidatun Nisa}

Social Science Education Department, Faculty of Social Science, Universitas Negeri Semarang, Indonesia

\section{Info Artikel}

Sejarah Artikel:

Disubmit Januari 2019

Direvisi Februari 2019

Diterima Maret 2019

\section{Keywords:}

source of learning, IPS, utilization, environment's school.

\begin{abstract}
Abstrak
Sumber belajar merupakan salah satu hal yang penting untuk diperhatikan oleh pendidik, sebagai jembatan pengetahuan pendidik dengan peserta didik. Pembelajaran pada mata pelajaran IPS guru biasanya menggunakan metode ceramah dalam menyampaikan materi pada siswa. Hal tersebut cenderung membuat pembelajaran membosankan. Fokus penelitian ini adalah menganalisis proses pemanfaatan lingkungan sekolah sebagai sumber belajar IPS terkait perencanaan, pelaksanaan, dan evaluasi serta kendala yang dihadapi guru dalam pemanfaatan lingkungan sekolah sebagai sumber belajar IPS. Teknik pengumpulan data yang digunakan adalah wawancara, obervasi, catatan lapangan, dan dokumentasi. Penelitian ini menggunakan teknik analisis data kualitatif. Hasil penelitian menunjukkan bahwa, guru IPS SMP Negeri di Kecamatan Sragen memanfaatkan lingkungan sekolah ruang lingkup dalam pagar sekolah sebagai sumber belajar IPS. Kendala yang dihadapi oleh guru IPS dalam memanfaatkan lingkungan sekolah sebagai sumber belajar, yakni sempitnya lahan sekolah, tidak tersedianya sarana dan prasarana, waktu, kemampuan guru, pengawasan, materi pelajaran, ketidaksiapan siswa, dan usia guru.
\end{abstract}

\begin{abstract}
Source of learning on teaching is most important thing for educator, as bridge knowledge between teacher with students. Usually learning of social science the teacher use speech method to give lesson for students. That is inclined make the learning boring. This research focused to analysis process of utilization environtment's school as source of learning, related planning, implementation and evaluation with obstacle that faced teacher when utilization source of learning environment's school. Technique collection of data is interview, observation, note of field, and documentation. This research use qualitative analysis. Result of research indicate that teacher IPS SMP Negeri in Kecamatan Sraegn utilize environment's school scope spcae in hedge's school as source of learning IPS. Obstacles that faced teacher when use source of learning environment's school is limited area school, material lesson, unavaible tool and infrastructure, time, ability of teacher, unreadliness students and teacher age
\end{abstract}

(C) 2019 Universitas Negeri Semarang

\footnotetext{
Alamat korespondensi:

Gedung C1 Lantai 1 FIS Unnes

Kampus Sekaran, Gunungpati, Semarang, 50229

E-mail: jurnalsosioliumpips@mail.unnes.ac.id
}

E-ISSN 2685-4929 


\section{PENDAHULUAN}

Pendidikan nasional memiliki fungsi mengembangkan kemampuan dan membentuk watak serta peradaban bangsa yang bermartabat dalam rangka mencerdaskan kehidupan bangsa, mengembangkan potensi peserta didik agar menjadi manusia yang beriman dan bertakwa kepada Tuhan Yang Maha Esa, berakhlak mulia, sehat, berilmu, cakap, kreatif, mandiri, dan menjadi warga negara yang demokratis serta bertanggung jawab (Undang-Undang Sistem Pendidikan Nasional No. 20 Tahun 2003). Berdasarkan pada pemahaman tujuan pendidikan nasional, seperti tercantum dalam UndangUndang Sistem Pendidikan Nasional No. 20 Tahun 2003, pendidikan yang dilaksanakan di sekolah bermakna sebagai proses pengembangan kemampuan dan penanaman karakter yang sesuai dengan tuntutan pembangunan negara. Beberapa permasalahan dalam pembelajaran IPS yang dianggap membosankan dikarenakan peserta didik tidak dirancang untuk berpikir kritis sehingga kurang mampu mengatasi permasalahan, peserta didik tidak dilibatkan dalam proses pembelajaran, pembelajaran masih dipusatkan pada guru, penggunaan media dan sumber belajar yang kurang menarik, metode pembelajaran yang monoton, guru belum memanfaatkan lingkungan sebagai sumber belajar (Ramawati, dkk, 2016:68). Sumber belajar merupakan salah satu faktor pendukung yang dapat mempengaruhi tingkat keberhasilan belajar siswa. Dalam pembelajaran IPS selain dari buku teks siswa, lingkungan merupakan sumber belajar yang cukup penting khususnya lingkungan sosial, hal tersebut dapat dilihat dari obyek yang dipelajari dalam materi pelajaran IPS, yang mana memiliki tujuan untuk mengenal konsep-konsep yang berkaitan dengan kehidupan masyarakat dan lingkungannya. Secara umum sumber belajar yang dapat digunakan dalam pembelajaran menjadi dua yaitu, sumber belajar yang sengaja dirancang secara khusus untuk pembelajaran (learning resource by design) dan sumber belajar yang tinggal dimanfaatkan (learning resource by utilization) (Suryadharma, dkk, 2017:1). Lingkungan dapat digunakan untuk sumber belajar yang tinggal dimanfaatkan dimaksudkan bahwa sekolah tinggal memanfaatkan apa saja yang tersedia di lingkungan sekitarnya sebagai sumber belajar. Lingkungan memiliki fungsi yang penting dalam pembelajaran, salah satunya yaitu berfungsi sebagai sumber belajar dan media pembelajaran di sekolah. Menurut para pakar pendidikan umumnya sepakat bahwa lingkungan berkorelasi positif terhadap keberhasilan pendidikan seseorang (Munib, 2012:71). Dalam kurikulum 2013 untuk SMP/MTS dijelaskan bahwa IPS merupakan mata pelajaran yang mengkaji tentang isu-isu sosial dengan unsur kajiannya dalam konteks peristiwa, fakta, konsep, dan generalisasi. Pada hakikatnya Ilmu Pengetahuan Sosial (IPS) merupakan ilmu pengetahuan yang menelaah manusia dalam hubungan sosialnya atau kemasyarakatannya (Fitriyani, 2015:29). Materi pembelajaran IPS diambil dari kehidupan nyata yang terdapat dari lingkungan alam maupun lingkungan masyarakat. Sebagian besar materi pelajaran IPS bersumber dan berkaitan dengan lingkungan sekitar. Akan tetapi, pembelajaran IPS di sekolah-sekolah masih hanya sebatas penjabaran konsep, masih sedikit sekolah maupun guru yang mengajak siswa untuk mengamati secara langsung pada lingkungan hidup ataupun lingkungan masyarakat sekitar.

$$
\text { Menurut Pantiwati }
$$
pemanfaatan lingkungan sebagai sumber belajar sesuai dengan konsep pembelajaran kontekstual. Pembelajaran yang lebih aplikatif, maksudnya materi belajar yang 
diperoleh siswa melalui pemanfaatan lingkungan kemungkinan besar akan dapat diaplikasikan langsung. Karena pemanfaatan lingkungan memberikan pengalaman langsung pada siswa dan lebih komunikatif. "Salah satu strategi pembelajaran kontekstual adalah dengan memanfaatkan lingkungan siswa. Lingkungan siswa sesungguhnya sangat bermacam-macam ditinjau dari jenisnya ada lingkungan alam, lingkungan sosial, dan lingkungan kebudayaan. Ditinjau dari lokasinya ada yang berada di lingkungan sekolah dan di luar sekolah. Lingkungan tersebut sangat membantu dalam pembelajaran kontekstual. Dalam hal ini lingkungan dimanfaatkan sebagai sumber belajar" (Purnamasari, 2011:14).

Kabupaten Sragen merupakan salah satu Kabupaten yang berada di Jawa Tengah, Kabupaten ini berbatasan dengan Kabupaten Grobogan di utara, Kabupaten Ngawi di timur, Kabupaten Karanganyar di selatan dan Kabupaten Boyolali di barat. Kabupaten Sragen letaknya berada di lembah daerah aliran Sungai Bengawan Solo yang mengalir kearah timur. Letaknya yang strategis menjadikan Kabupaten ini sebagai jalur utama sebelah timur Provinsi Jawa Timur. Di Sragen juga terdapat situs sejarah yang terkenal yakni Museum Fosil Sangiran, yang mana dapat dijadikan sebagai salah satu sumber belajar IPS khususnya mata pelajaran sejarah. Kecamatan Sragen adalah pusat pemerintahan di Kabupaten Sragen. Terdapat 6 SMP negeri dan 6 SMP swasta di Kecamatan Sragen. Berdasarkan pemaparan latar belakang yang dijelaskan diatas, maka peneliti mengambil judul berupa "Pemanfaatan Lingkungan Sekolah Sebagai Sumber Belajar IPS Oleh GuruGuru SMP Negeri di Kecamatan Sragen".

\section{METODE}

\section{Alat dan Teknik Pengumpulan Data}

Terdapat dua hal utama yang mempengaruhi kualitas data hasil, yaitu kualitas instrumen penelitian dan kualitas pengumpulan data. Pengumpulan data dapat dilakukan dalam berbagai sumber dan cara (Sugiyono, 2015). Alat dan teknik pengumpulan data yang digunakan dalam penelitian adalah wawancara, observasi, catatan lapangan, dan dokumentasi.

\section{Uji Keabsahan Data}

Penelitian ini menggunakan triangulasi sumber dan teknik pengumpulan data, yakni pengecekan data dari berbagai sumber dengan berbagai cara sebagai berikut:

1. Triangulasi dengan tiga sumber data

2. Triangulasi sumber dilakukan untuk menguji kredibilitas data dengan cara mengecek data yang diperoleh melalui Guru IPS, kepala sekolah dan siswa di masing-masing SMP.

3. Triangulasi dengan tiga teknik pengumpulan data

4. Triangulasi teknik dilakukan untuk menguji kredibilitas data dengan cara mengecek data kepada sumber yang sama dengan teknik yang berbeda yaitu wawancara, catatan lapangan, observasi dan dokumentasi.

\section{Teknik Analisis Data}

Analisis data kualitatif dilakukan pada saat pengumpulan data sedang dilaksanakan, dan setelah selesai pengumpulan data dalam waktu tertentu. Menurut Miles dan Huberman (1992) aktivitas menganalisis dilakukan secara interaktif dan berlangsung secara terus menerus sampai tuntas, sehingga data yang diperoleh sudah jenuh. Tahapan dari analisis tersebut adalah reduksi data, penyajian data, dan penarikan kesimpulan. 


\section{PEMBAHASAN}

Proses Pemanfaatan Lingkungan Sekolah Sebagai Sumber Belajar IPS oleh Guruguru SMP Negeri di Kecamatan Sragen

\section{Perencanaan}

Perencanaan yang dimaksudkan dalam hal ini adalah pembuatan RPP juga pengidentifikasi potensi lingkungan sekolah yang dapat digunakan sebagai sumber belajar IPS. Hal pertama yang perlu dilakukan oleh seorang guru adalah mencari potensi lingkungan sekolah yang dapat dijadikan sumber belajar IPS. Berdasarkan pada wawancara dan dokumentasi pada guru IPS maka dapat diketahui bahwa sebagian besar guru telah merencanakan pembelajaran dengan membuat RPP. Rencana pembelajaran yang menggunakan lingkungan sebagai sumber belajar dan sumber materi pelajaran terdapat pada beberapa materi dan pada setiap kelas. Kemudian setelah inventarisasi potensi lingkungan sekolah, guru dapat membuat identifikasi kesesuaian objek lingkungan dengan $\mathrm{KD}$.

\section{Pelaksanaan}

1. Lingkungan dalam pagar sekolah Terdapat beberapa bentuk pemanfaatan lingkungan sekolah ruang lingkup dalam pagar sekolah, ada beberapa guru yang tetap mengajar didalam kelas seperti bu Ninik yang memberi tugas berupa pengamatan interaksi antarteman, selain itu bentuk lain adalah mengajak siswa untuk keluar kelas seperti bapak Sutomo member tugas membuat lubang biopori disekitar sekolah dan bapak Pratiwanggono yang meminta siswanya untuk berjualan disekitar sekolah juga tugas pengamatan tanaman sekitar sekolah yang dilakukan oleh bapak Sumarno.

2. Lingkungan diluar pagar sekolah terjangkau saat jam pelajaran
Bentuk pemanfaatan lingkungan sekolah yang terjangkau saat jam pelajaran adalah pengamatan kondisi masyarakat sekitar rumah siswa seperti tugas dari bu Ninik, pengamatan pasar malam setiap setahun sekali di Sragen atau yang disebut dengan cembreng, ada juga mencari data jumlah penduduk di rumah siswa.

3. Lingkungan di luar pagar sekolah tidak terjangkau saat jam pelajaran

Berdasarkan pendapat guru terkait pemanfaatan lingkungan sekolah sebagai sumber belajar IPS semua sekolah pernah mengajak siswanya untuk belajar di luar sekolah seperti SMP Negeri 1 Sragen yang mengajak siswanya ke Jogja yang merupakan salah satu program sekolah Outing Class khusus kelas 7 yang biasanya diadakan satu kali dalam setahun. Sama dengan SMP Negeri 2 Sragen yang juga diajak keluar sekolah seperti ke pabrik teh di Jawa Timur, kegiatan tersebut juga ditujukan pada kelas 7. Setelah kegaiatan biasanya siswa diberikan penugasan laporan. Di SMP Negeri 3 Sragen juga ada program saat Moving Class siswa diajak ke Museum Sangiran dan Keraton Solo. Setelah kegiatan Outing Class, Moving Class maupun kunjungan tempat siswa diberi tugas berupa pembuatan laporan. Sedangkan, untuk kelas 8 ada study tour, di SMP N 3 Sragen melaksanakan study tour pada bulan Maret dengan tujuan Bali.

\section{Evaluasi}

Hasil dari dokumentasi dan wawancara guru pada tahap terakhir yaitu evaluasi atau tindak lanjut dari pelaksanaan pembelajaran IPS di sekolah, sebagian besar guru memberikan tugas berupa pengamatan di lingkungan sekitar siswa maupun di sekitar sekolah. Untuk hasil belajar siswa, semua siswa telah melampaui KKM yang telah ditentukan oleh guru. Sehingga, pembelajaran yang sudah direncankanan dan dilaksanakan oleh guru telah mampu 
mencapai tujuan pembelajaran. Bentuk dari tugas ada beberapa macam yakni ada pembuatan video, laporan, makalah, ada juga berupa simulasi langsung.

\section{Kendala-kendala Guru dalam Memanfaatan Lingkungan Sekolah Sebagai Sumber Belajar IPS SMP Negeri di Kecamatan Sragen}

Kendala-kendala yang dihadapi guru ketika memanfaatkan lingkungan sekolah sebagai sumber belajar IPS menemui beberapa kesulitan, seperti kemampuan guru dalam merencanakan pembelajaran, kendala terhadap waktu, sarana dan prasarana yang kurang mendukung, dan antusias siswa terhadap pembelajaran IPS dengan memanfaatkan lingkungan sekolah sebagai sumber belajar IPS.

\section{SIMPULAN}

\section{Simpulan}

Proses pemanfaatan lingkungan sekolah sebagai sumber belajar IPS terkait perencanaan guru sudah merencanakan pembelajaran dengan membuat RPP dengan mengidentifikasi lingkungan sekolah yang dapat dijadikan sebagai sumber belajar, terkait pelaksanaan terdapat beberapa bentuk kegiatan pembelajaran yang dilakukan oleh guru ada yang diajak ke lapangan secara langsung ada juga siswa diajak secara tidak langsung dengan mengamati lingkungan sekitar. Ketiga sekolah memanfaatkan tiga ruang lingkup yakni dalam pagar sekolah, di luar pagar sekolah yang terjangkau jam pelajaran dan di luar pagar sekolah yang tidak terjangkau jam pelajaran. Untuk hasil evaluasi atau hasil belajar siswa, dapat diketahui bahwa nilai siswa sudah mencapai KKM serta tindak lanjut pembelajaran berupa pemberian tugas kepada siswa yaitu membuat video, kliping, laporan atau makalah.
Kendala-kendala yang dihadapi guru ketika memanfaatkan lingkungan sekolah sebagai sumber belajar IPS menemui beberapa kesulitan, seperti kemampuan guru dalam merencanakan pembelajaran, kendala terhadap waktu, sarana dan prasarana yang kurang mendukung, dan antusias siswa terhadap pembelajaran IPS dengan memanfaatkan lingkungan sekolah sebagai sumber belajar IPS.

\section{Saran}

Bagi pihak sekolah, hendaknya memanfaatkan lingkungan secara maksimal untuk digunakan sebagai sumber belajar siswa sehingga dapat mendukung guru dan siswa dalam proses pembelajaran yang kontekstual.

Bagi guru, hendaknya mau berinovasi dengan sumber belajar IPS lain yang biasa digunakan dan mengaitkan pembelajaran dengan lingkungan sekitar siswa agar pembelajaran IPS lebih kontekstual.

Bagi peneliti selanjutnya, mampu mengidentifikasi dan menganalisis secara mendalam pemanfaatan lingkungan sekolah sebagai sumber belajar IPS.

\section{DAFTAR PUSTAKA}

Fitriyani, Nia. 2015. 'Pengaruh Penggunaan Strategi Pembelajaran Berbasis Pendekatan Terhadap Hasil Belajar Siswa Pada Mata Pelajaran IPS'. Skripsi. Jakarta: Fakultas Ilmu Tarbiyah dan Keguruan.

Miles, Mathew B. dan A. Michael Huberman. 1992. Analisis Data Kualitatif: Buku Sumber Tentang Metode-Metode Baru. Penerjemah: Tjetjep Rohendi Rohidi. Jakarta: Universitas Indonesia.

Pantiwati, Yuni. 2015. 'Pemanfaatan Lingkungan Sebagai Sumber Belajar Dalam Lesson Study Untuk Meningkatkan Metakognitif'. Dalam Jurnal Bioedukatika. No $1 \mathrm{Hal} 27-$ 32. 
Oktania Nelly Kusani, dkk / Sosiolium 1 (2) (2019)

Purnamasari, Iin. 2011. 'Pengembangan Pembelajaran IPS Terpadu Berbasis Lingkungan Sekitar'. No 1 Hal 12-17.

Ramawati Isye, dkk. 2016. 'Pemanfaatan Lingkungan Sebagai Sumber Pembelajaran Untuk Meningkatkan Kemampuan Berpikir Kritis'. Dalam Jurnal Pendidikan Geografi. No. 1 Hal. 6687.
Sugiyono. 2015. Metode Penelitian Pendidikan. Bandung: Alfabeta.

Suryadharma, dkk. 2017. Panduan Pemanfaatan Lingkungan Sekolah Sebagai Sumber Belajar Sekolah Menengah Pertama. Kementerian Pendidikan dan Kebudayaan. (diunduh pada tanggal 6 Februari 2018).

Undang-undang Nomor 20 Tahun 2003 Tentang Sistem Pendidikan Nasional (diunduh melalui www.polsri.ac.id pada tanggal 19 April 2017 pukul 13:09 WIB 